\title{
A VISIT TO KERAK AND PETRA.
}

\section{By Charles Alexander Hornstein, Esq.}

IN September, 1895, I was invited by Mr. Forder (C.M.S., Kerak) to spend a few days at Kerak. He had come over to Jerusalem to fetch his wife and child. I had often wished to visit this very interesting city, and was glad of the opportunity now afforded me. We thought we would shorten the journey by engaging the Government boat which from time to time goes across the Dead Sea to the Ghor el Mizrah. We were successful in securing it, so Mr. Forder sent a man on to Kerak to bring animals down to the Ghor to wait for us. The following day we drove

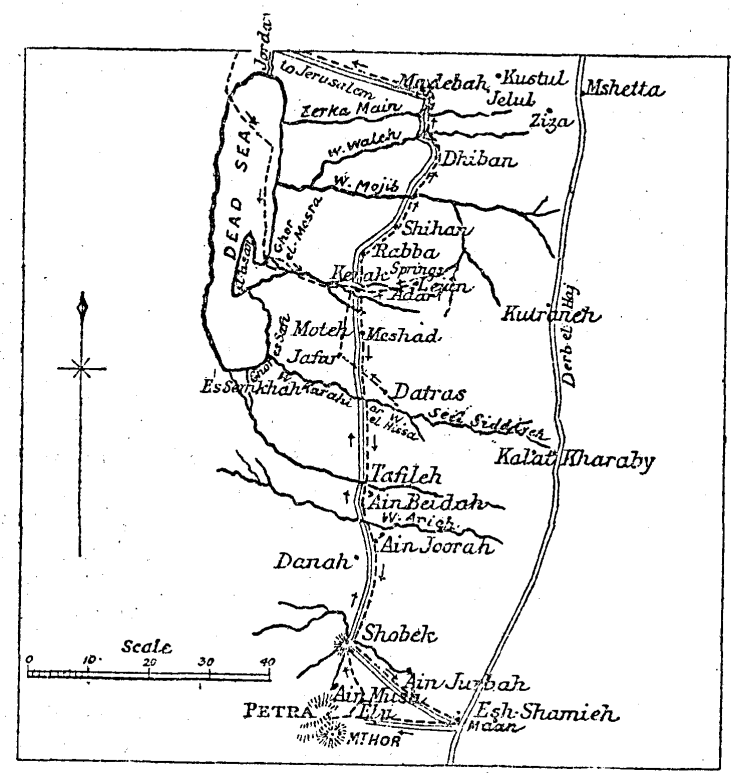

Map of Route to Kerak and Petra.

down to the Dead Sea, which we reached at 6 o'clock p.m. Here we found the two boatmen waiting for us, and shortly after, a breeze springing up from the north-west, we set sail and were soon shooting across the sea. At first we took a south-easterly course, and in about three hours' time got close to the opposite shore, then turning to the south we ran along the coast for the next four hours. Shortly after midnight the moon rose, and by its feeble light we could see the "Lisan" rising like a wall out of the sea on our right. 
(To face P. 94.)

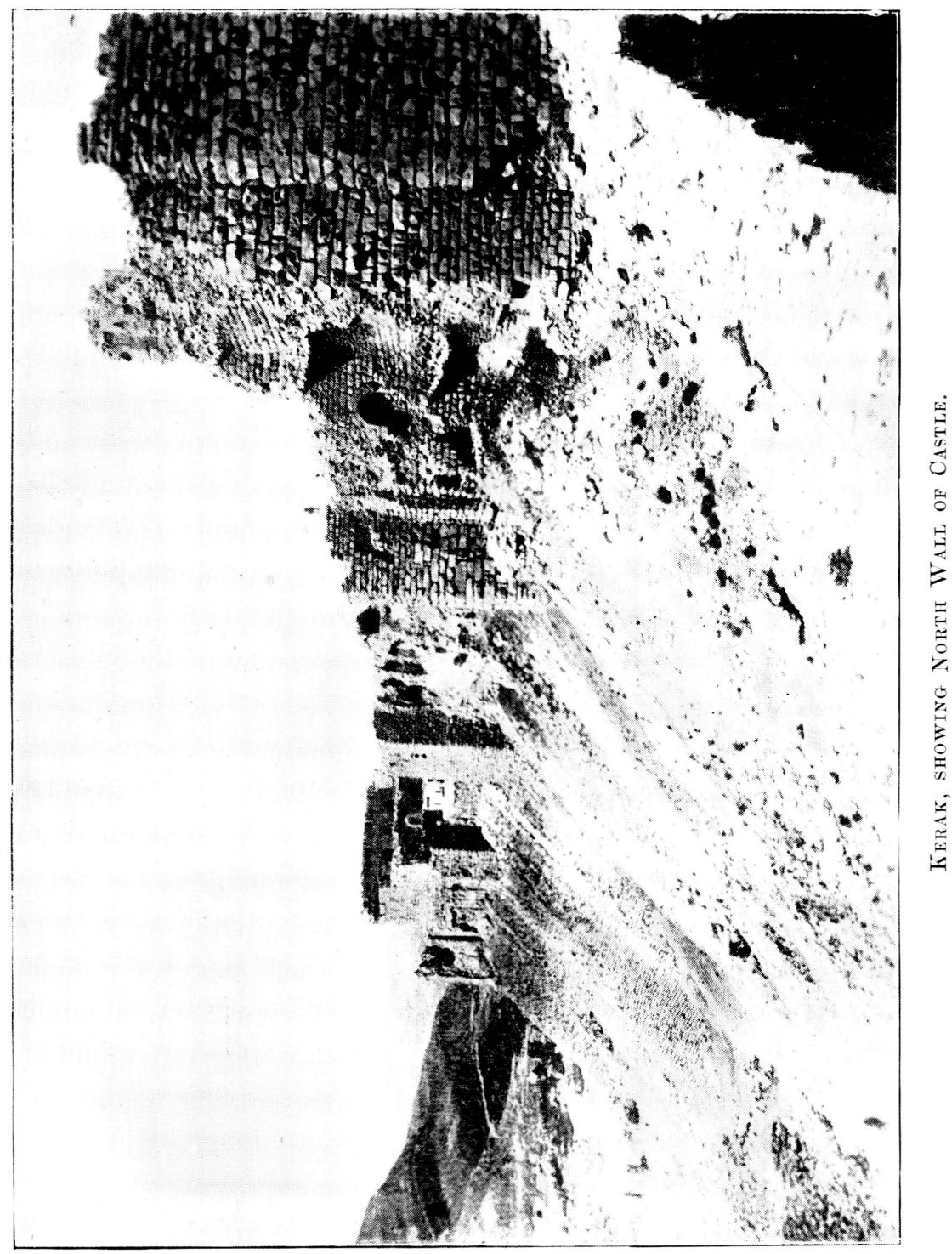




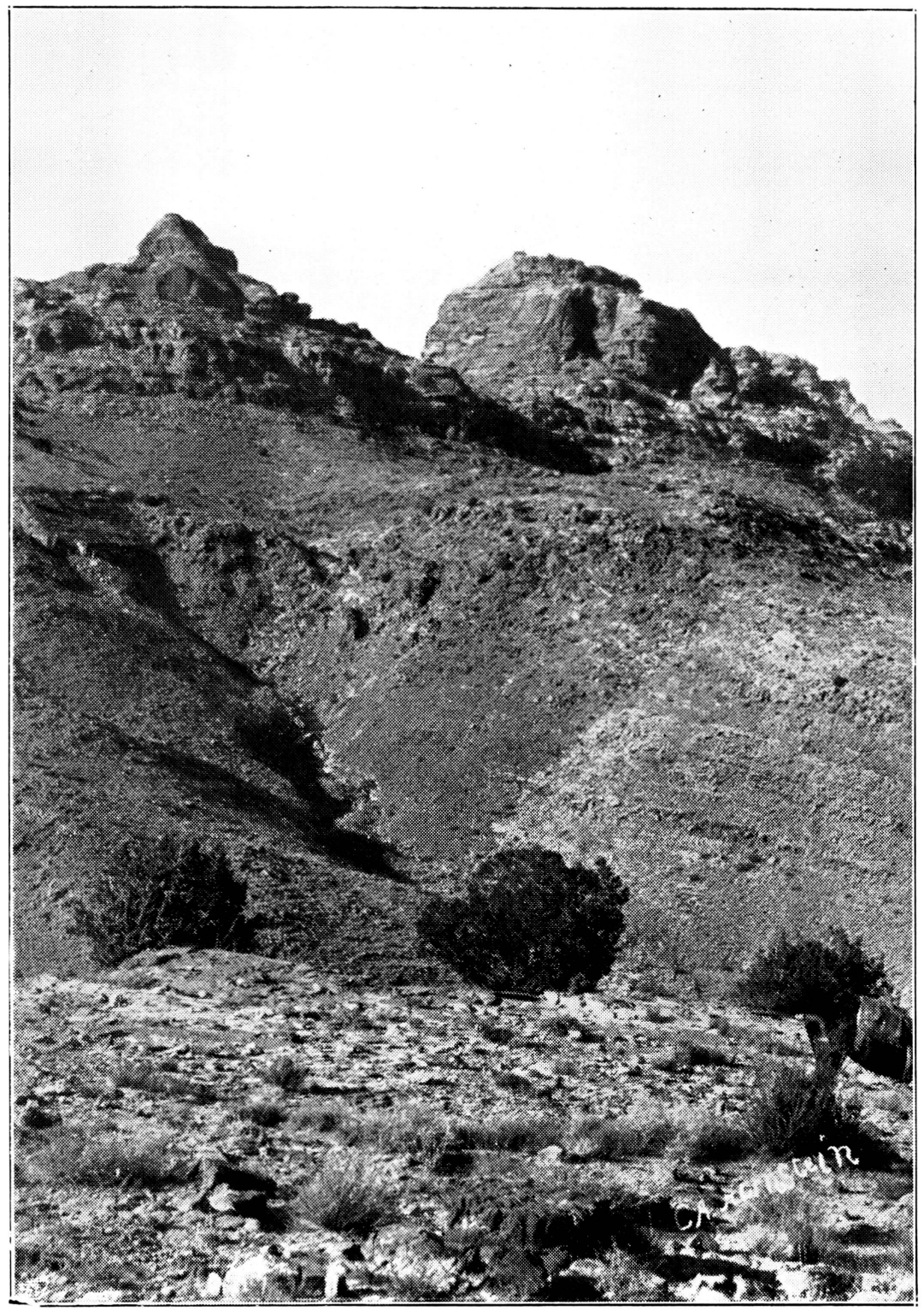

Mount Hor. 
About 1 o'clock a.m. we got near the landing place. 'The breeze all the time had been growing stronger, and the waves rose rapidly. Suddenly we felt a shock and stopped short. We had run against a sand bank. One of the boatmen jumped out and tried to shove the boat off, but to no avail. We next tried to lighten her by throwing a number of iron girders and planks that we had on board into the sea; still she held fast. The waves meanwhile kept breaking over us, drenching us. All our efforts having proved fruitless we decided that the best thing to be done was to make ourselves as comfortable as we co:ald under the circumstances and wait for daybreak. We should have attempted to get ashore, for we were not more than 300 yards off, but we could not tell how deep the water might be. At 6 o'clock one of the boatmen said he would go ashore and bring help, as he knew of an encampment two hours off. He got to shore safely, and, finding the men who had come down from Kerak with our animals, sent them to our assistance. With their help we managed to wade through safely. We then mounted our animals and riding for a quarter of an hour reached a tent which our men had pitched. We soon had a kettle boiling and enjoyed a delicious cup of tea. The hot sun dried our clothes in a few. minutes and we forgot all the discomforts of the past night.

The Ghor el Mizrah is a lovely spot, covered with trees, through which flow streams of fresh, clear water. Pigeons and partridges abound. The Wady Kerak flows through this Ghor and empties itself into the sea. As soon as it began to get cool we mounted our animals and started for Kerak. The ride is a continual ascent for seven hours. We stopped twice on the road to rest, and shortly after 3 a.m. reached the city. In the evening Mr. Forder and I went to pay our respects to the Governor, Helmy Bey Effendi. He received us very courteously and showed us a number of views that the son of the Waly of Damascus had taken; amongst them were three of Petra. I asked him if it was necessary to get a special permit from Constantinople to visit the ruins of Petra, as I had heard that he had refused to let some travellers go who had applied to him. He said that up to the present he had not allowed any travellers to visit the place, but if I wished to go he would give me permission and provide me with an escort. This was quite unexpected, and an offer not to be refused, so I thankfully accepted. I had brought only one dożen plates with my camera, so Mr. Forder suggested sending a messenger to Jerusalem for some more. We found a man willing to undertake the journey for three medjiedies, promising to be back in five days' time. The next day Mr. Forder took me round to all the places of interest, such as the Castle, the Roman bath, the Western or Bybar's Tower, which have all been so fully described by De Saulcy, Canon Tristram, and Dr. Bliss that it will not be necessary for me to say anything about them. On a knoll outside the city, opposite Bybar's Tower and a little to the north-west, is a tomb about 9 feet long. The natives believe this to be Noah's Tomb (Siddna Nuh). It is covered with broken pieces of glass, bits of pottery, hennah, and sticks with pieces of 
various coloured rags tied to them. These have been presented to the Weli as votive offerings. One place of interest, which I do not think has ever before been noticed, is the tunnel which runs underneath the castle at its south-east corner. Mr. Forder's attention was drawn to this tunnel by some Bedouin in September, 1893. None of them had ever entered it, as they were too much afraid of evil spirits, so one day Mr. Forder and Miss Arnold went down to explore it. The opening was merely a hole large enough for them to squeeze through. At the time I went there the entrance had by the Mutassarif's orders been cleared out. This tunnel is cut out of the solid rock and runs in a westerly direction. Its average width is $4 \frac{1}{2}$ feet. About 10 yards from the entrance is an opening in the floor $7 \frac{1}{2}$ feet long by 4 feet wide, nearly the width of the passage, leaving a narrow ledge, 6 inches wide, on the left hand side. By placing the right hand against the opposite wall we managed with great care to step along the ledge.

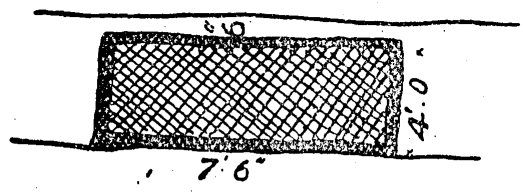

There are eight of these holes or openings, the distance between each being from 12 to 30 yards. Soon after passing the last opening we came to a drop of about 8 feet, which landed us on to a lower passage or aqueduct. This one runs in a westerly direction for abont 50 yards and stops at a solid wall of rack from which trickles a small stream. Towards. the east this lower passage runs parallel to the top one, till passing under the fourth.opening from the west end it takes a turn to the north and winds round to the fifth opening; from here it continues to run parallel to the top passage.

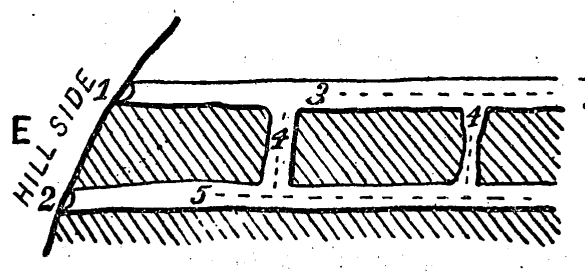

1. Gpening to top passage.

2., lower passage.

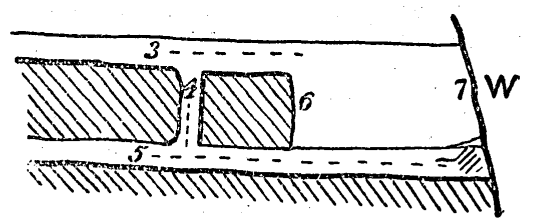

4. Shaft to lower passage.

5. Lower passage.

6. Drop to passage.

7. Rock.

The width of this lower passage, where it conmences to run underneath the other, is not more than 18 inches; at the bend it is about 1 foot; underneath the first hole from the entrance, a little over 3 feet; its depth beneath this hole is nearly 20 feet. It is difficult to say what the 


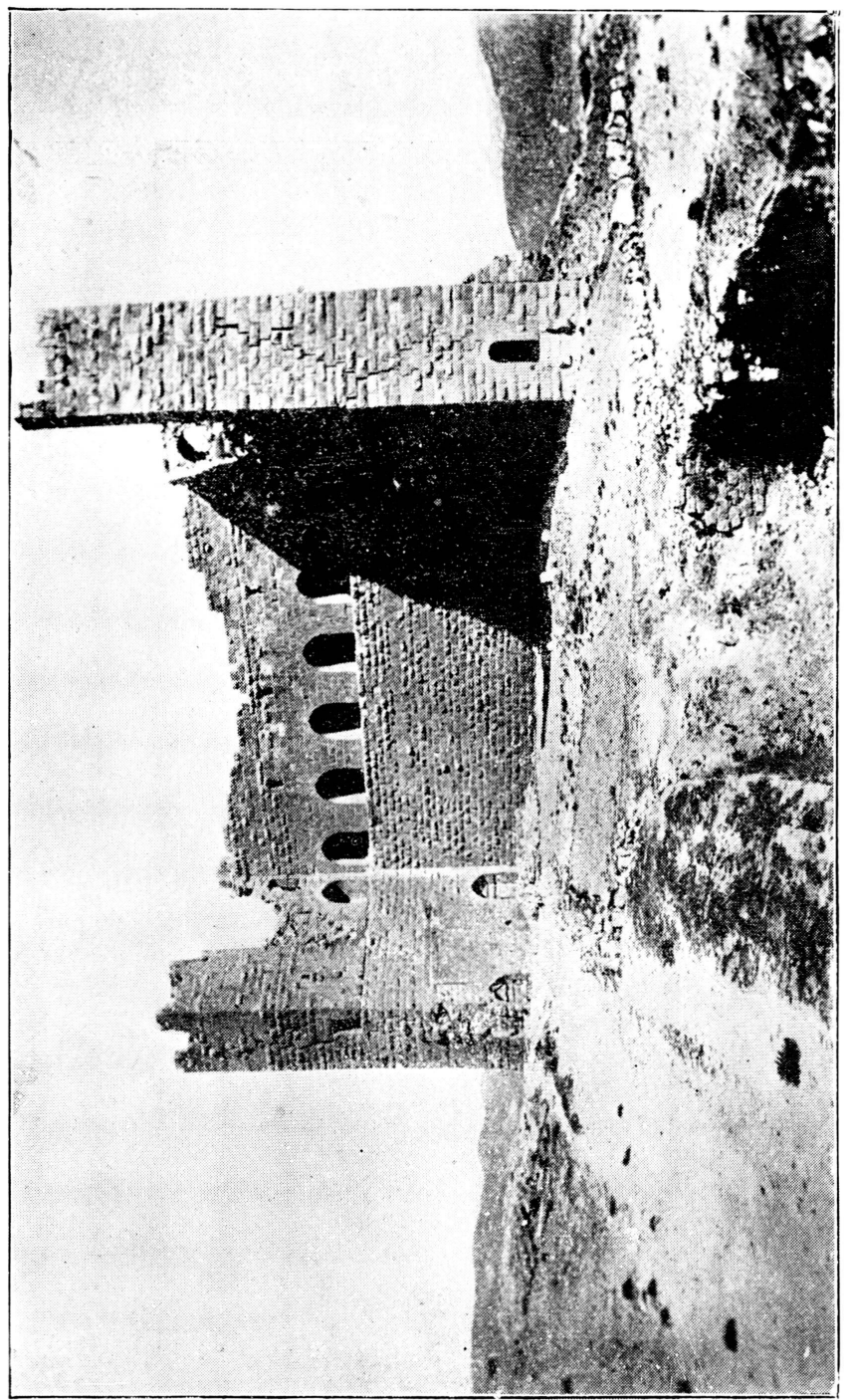

告 
object of this tunnel could have been, as it stops at the rock, and there are no side passages.

The next day we went out to Lejûne. The road, after crossing the Wad ez Zaiyatain, lies across the plain, which at this time of year was perfectly barren, except for the kilo or alkali plant. We passed some Bedouin encampments, and the ruins of Adar. In four hours' time we reached Lejûne, which is situated in a little plain. On the north is a stream which flows eastwards for a few miles, then turning towards the north flows into the Arnon. This stream forms the Wady Lejune. The town itself appears to have been a military station for cavalry. It is rectangular, and has a strong wall round it, with gates on the four sides. The north and south gates are triple, the east and west single. It was divided into four squares by two streets which crossed each other at right angles. The north-east, north-west, and south-west squares were enclosed by chambers, traces of which can still be seen. The courtyards in all probability must have been used for tying the horses in, and the chambers were for the use of the soldiers. In the south-east square is a mass of ruins. I hunted all over for inscriptions but did not find any. On a little hill to the west is a raised platform, about 40 yards square, with a few stejs leading up to it. A number of large stones lay about, and several pieces of columns. The walls of this platform had been used by the Bedouin as a burying ground. Most of the graves were marked by a stick with a bit of rag tied to it. This must have been a watch-tower of some kind, as it commands a good view of the surrounding country. As it was getting late now, we returned home. On the evening of the fifth day our messenger, true to his promise, returned with the plates; we went up to the Mutassarif and told him we would like to start for Petra the next morning. He kindly gave us two letters of introduction, one to the Kaimakam of Tafileh, and the other to the Kaimakam of Ma'an; and said that two soldiers would be ready to accompany us next morning.

We, Mr. Forder and I, started at 7 a.m., and passing the Seraiyah, or Government house, were joined by two Circassian cavalry men. Our road lay past 'Ain Sit. At 9.15 we reached El Mesh'had, or the Place of Witness. It is an old ruin on the roadside, and contains several Arabic inscriptions. The tradition among the Bedouin about this place is that the prophet Mohammed sent his cousin Ja'far with a large army against the Christians who lived in Moteh, a village to the right of the road, and a short distance from El Mesh'had. The prophet's army was defeated, and Ja'far fatally wounded. As the Christians surrounded him, he suddenly rose and flew across the plain to the top of a little hill, about three miles off to the south-west, where he died. His tomb is still to be seen. In consequence of this wonderful deed he is called "Ja'far el Taiyar"-Ja'far the Flyer. Ali Abu Talib, who was an eye witness, swears to the truth of it. Hence the name of the place from which he flew is called "El Mesh'had."

At 11.20 we reached the Wad el Ahsa, or Hissa, which in its upper 
course is called "Wad el Siddiyeh" and "Seil Gharaby,". and in its lower course, "Wad el Kurahi." It forms the southern boundary of the district of Kerak. It took us nearly an hour to descend the narrow, rough, winding path to the bottom of the valley. A stream Hows through it bordered by thick oleander bushes. We rested here a short while for lunch and then commenced the ascent. The path this side was not as rough as the other, though it was much longer. Riding along this path, I noticed a great number of fossil shells. We reached the top at 3.50. A little before sunset we came in sight of Tafileh. We were now in the district of Jebâl (Gebal, mentioned in Psalm lxxxiii, 7). Tafileh, the ancient Tophel (Deut. i, 1), is a large village comprising 700 houses. It is beautifully situated on the side of a hill with a well-watered and well-cultivated valley below it, with olive groves, vineyards, and fig gardens. No less than eight springs are to be found in and around the village. We went direct to the Kaimakam's house and gave him the letter of introduction we had from the Mutassarif. He entertained us very hospitably, and gave us a room in the Seraglio as we had no tent with us. The next morning at 8 o'clock we started. We had three soldiers added to our number. At 9.40 we reached 'Ain el Beidah, a strearn of clear, cold water which runs right across the road. Here we stopped for a few minutes to water our horses, and watched the shepherds giving their flocks a drink. One hour brought us to Wad el Ârieh, through which flows a narrow muddy little stream. At 11.40 we reached 'Ain Joorah, a little pcol of water hidden amongst the rocks close to the roadside. Here we rested awhile to lunch. Soon afcer leaving 'Ain Joorah we passed Dânah, a little village situated in the valley to the right of the road. About one and a half hours later we came in sight of Shobek, and although it seemed hardly two hours off it took us nearly four hours to. get there, as the road winds round considerably.

Esh Shobek is the principal place of the district called Esherâh. It is a walled city built on a high hill and has only one gate. The road leading up to it is rough and winding. There are from 50 to 70 houses in the city-mostly in ruins. Baldwin II erected a castle here and called it Mont Regalis or Mont Royal, the remains of which, as well as those of the church, can still be seen. Many of the ruins are of Arabian origin. In time of war the inhabitants were supplied with water from a spring, which is right in the heart of the hill and to which one descends by 372 steps, partly cut out of the rock. The valley of Shobek is well watered and cultivated, the principal fruit being figs. When the Government took this part of the country in 1893 they placed here a small garrison of mounted soldiers. In May, 1895, some trouble arose between the soldiers and the inhabitants. The former tried to compel the women to draw water for their horses; the men refused to allow them and a quarrel ensued, which resulted in the soldiers being turned out of the city. The inhabitants immediately brought provisions into the city and shut the gate. A message was sent to them from the Mutassarif telling them to surrender. They answered that they were perfectly willing 
(To face P. 99.)

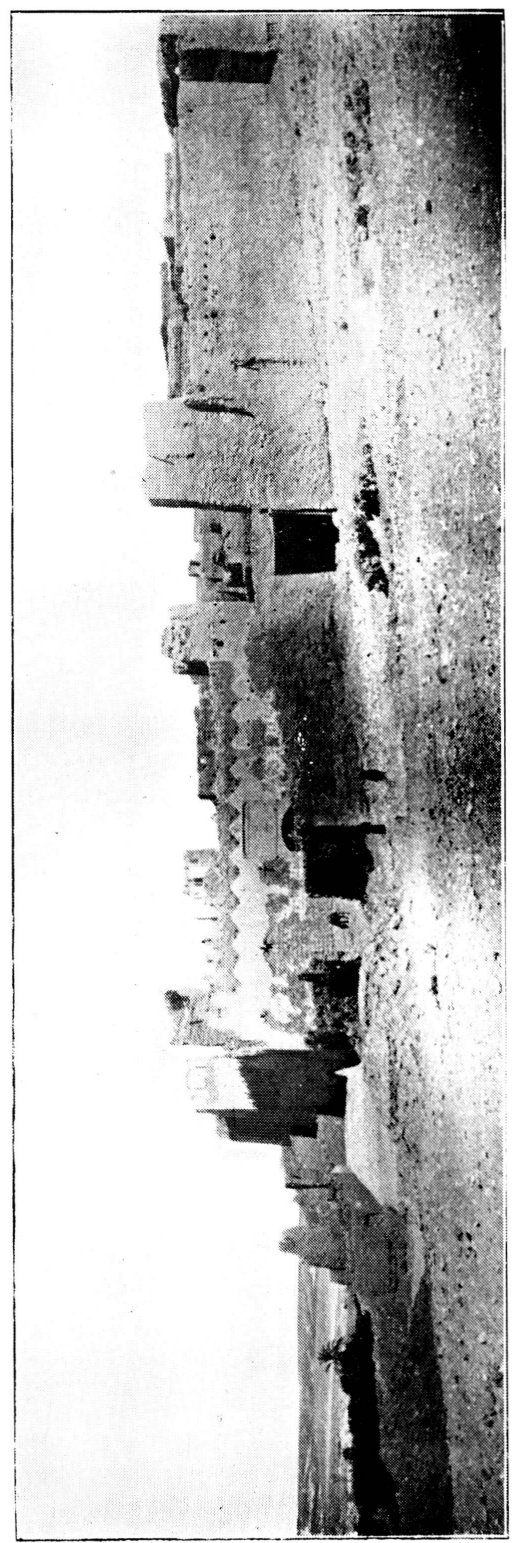

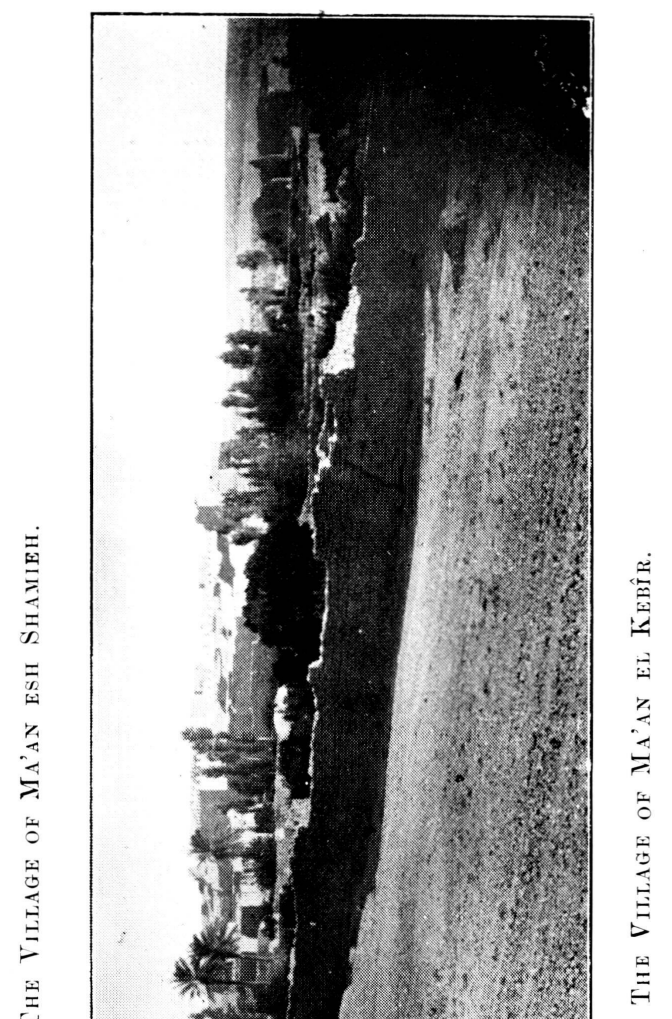


to pay all the taxes imposed on them, but would not allow any soldiers to enter the city. About 600 foot soldiers, with two cannon, and 100 cavalry were then sent to try and compel them to surrender. They pitched on the hills opposite Shobek. For some weeks little was done beyond an occasional skirmish. The Bedouin of the surrounding country hearing about the disturbance came to the assistance of the Shobekies. One day the soldiers, watching their opportunity, attacked the Bedouin, and with the help of the cannon drove them off, killing a great many. They eventually took the city, and placed a sufficient body of soldiers to guard it. The Circassian lieutenant, Omar Effendi, who was in charge, and with whom we stayed, received us very kindly and showed us all over the place. The next morning at 8 o'clock we left Shobek. Four hours' ride across a barren plain brought us to 'Ain Jurbah. Here we found a number of Bedouin horses that, owing to the exceptionally bad crops that year, had been turned out to graze on the scanty herbage growing around the 'Ain. Three of the animals had died. We stayed here some time to lunch and rest our horses, then continuing our journey reached Ma'an at 5 o'clock. We called on the Kaimakam and gave him the letter from the Mutassarif. He was extremely kind and invited us to stay with him. There are two Ma'ans situated on the Derb el Haj or Pilgrim Road, about a quarter of an hour distant from each other. The one to the north is called Ma'an esh Shamieh, or El Izghier; the other, Ma'an el Kebir. Both are built chiefly of mud bricks. The inhabitants are very polite and seem altogether of a class superior even to the Fellahîn around Jerusalem. There are a great many gardens and orchards, with streams of water flowing through them. A little to the east of Esh Shamieh are the remains of an aqueduct. We followed it for some distance, and came to the ruins of some watermills and a very large pool. Passing these, we came to the ruins of what must at one time have been a large village.

Ma'an is one of the halting-places of the pilgrims, who go from Damascus to Mecca. We stayed here till the next afternoon. At 1 o'clock we started, accompanied by five soldiers and the sheikh of Ma'an. Our road lay across the plain in a north-westerly direction. About sunset we came in, sight of Mount Seir, and shortly afterwards began descending towards the village of Elji, which we reached at 7.30 p.m.

Mount Seir, the Edom of Moses' days, is the range of mountains where Esau lived (Gen. xxxvi, 8, 9). In Deut. ii, 5, the children of Israel are told not to molest the Edomites, for God had given this mount to Esau. The length of this range is estimated at 100 miles, and its breadth 15 miles. During the Babylonish captivity, the Edomites took possession of the southern part of Judea, but were afterwards conquered by the Maccabees, and compelled to receive circumcision. Elji is situated on the slope of a hill. $j$ It is a stone village of about 50 houses, surrourded by vineyards, \&c. On our arrival we were taken to a Mudâfeh, or Guest Tent, as the inhabitants at this time of the year 
live out of doors. We had some coffee, and in an hour's time supper, which consisted of meat cooked with bread and tomatoes, was served; we made a hearty meal, and then tucked ourselves up in our blankets, and turned in for the night. We rose early the next morning to visit the ruins of Petra. Taking two of the sheikhs and a soldier we rode down to the Wady Mûsa. The valley gets its name from 'Ain Mâsa, which flows through it; it rises above the village of Elji. The tradition amongst the Mohammedans is that this was the scene of the striking of the rock by Moses. It is said that when he struck the rock 12 streams burst forth.

When we reached the valley we were joined by two villagers. About .20 minutes from the village we came to the commencement of the ruins. The most noticeable: are a temple with Corinthian columns and several tombs. Passing along the valley, which is covered with oleander bushes, through which we had in several places to force our way, we came to the Sik.

The Sik is a narrow passage or chasm between high rocks, which rise on either side from 80 to 200 feet; it is about 10 feet wide in the narrowest part, and about 40 feet in the widest. The bottom of the passage is covered with oleander bushes through which the waters of 'Ain Mâsa flow, whilst from the rocks and crevices above hang creepers, wild fig, and tamarisk. The length of this passage is nearly one mile.

Riding along the Sik we saw some cuttings and niches in the rocks which at one time may have contained inscriptions or statues. Half an hour after entering the Sik we came suddenly upon the temple called Khasneh Phar'aun (Pharaoh's treasure-house). It is cut out of the solid rock. The façade is of a lovely roseate tint. The Khasneh consists of two storeys. Five of the six columns which were in front of the porch are still standing. Entering the porch we found three doors. Those on the right and left lead to two chambers. The middle one leads to a large chamber, about 40 feet square, on three sides of which are again doors leading to three smaller chambers. These are unadorned except by the natural colour of the rock, which displays a variety of the most delicate tints. The top storey is solid; it consists of what may be called three towers. The centre one is round and terminates in a dome surmounted by a stone urn, which the natives believe contains Pharaoh's treasures : hence the name Pharaoh's Treasure-house.

- On the three towers and between them are beautiful sculptures, representing winged female figures. The whole space in front of the Khasneh is covered with oleander bushes. Turning to the right and following the valley: we passed a number of tombs of various shapes and sizes. One has a peculiar arrangement of graves cut out in the floor; on the wall of this tomb are two inscriptions. Right opposite these tombs is the amphitheatre which is hewn out of the rock. Thirtythree rows of seats rise one above another. Following the valley, which now turns to the north-west, and passing several ruins of what must have been temples, we came to the remains of a triumphal arch; close to this 


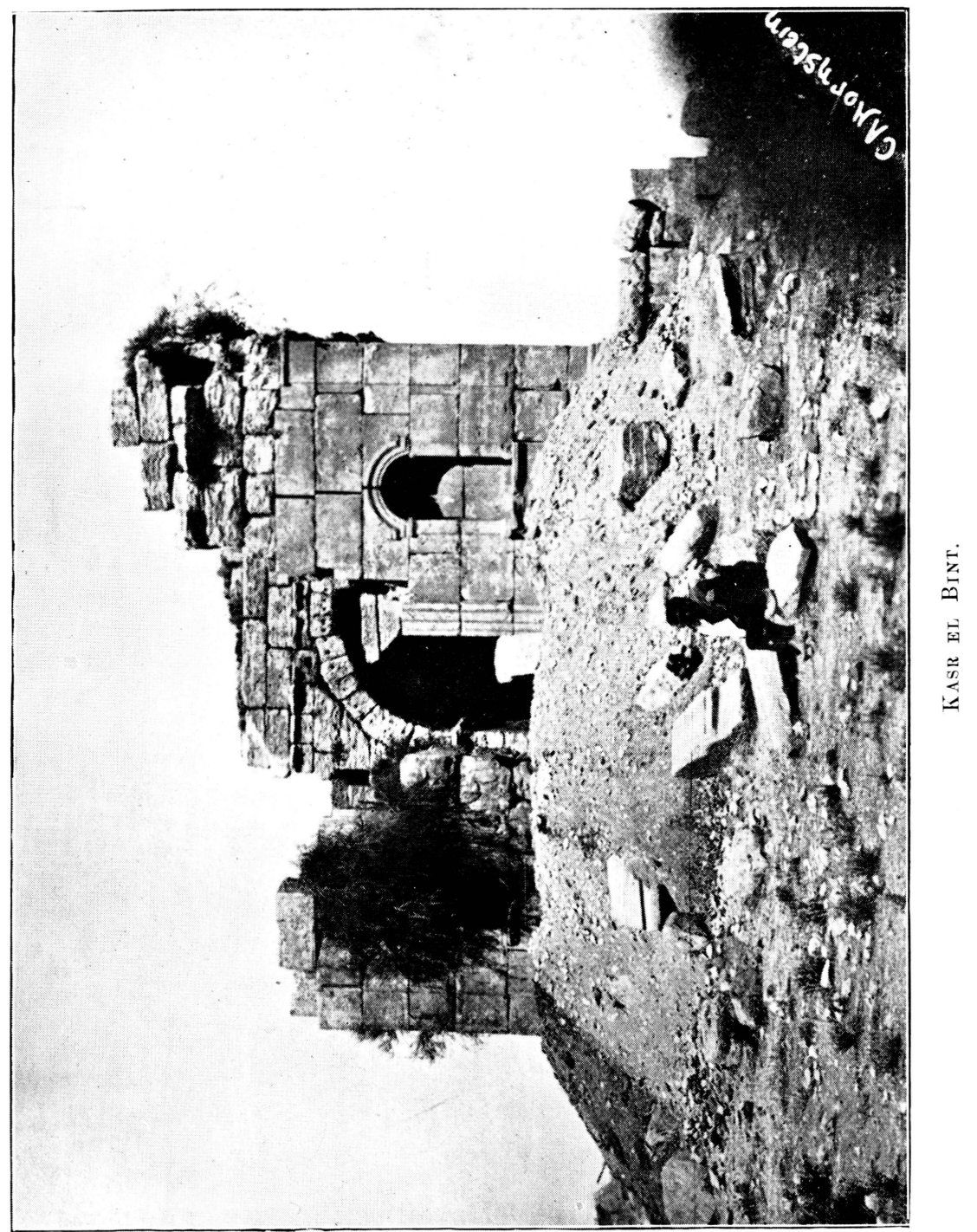




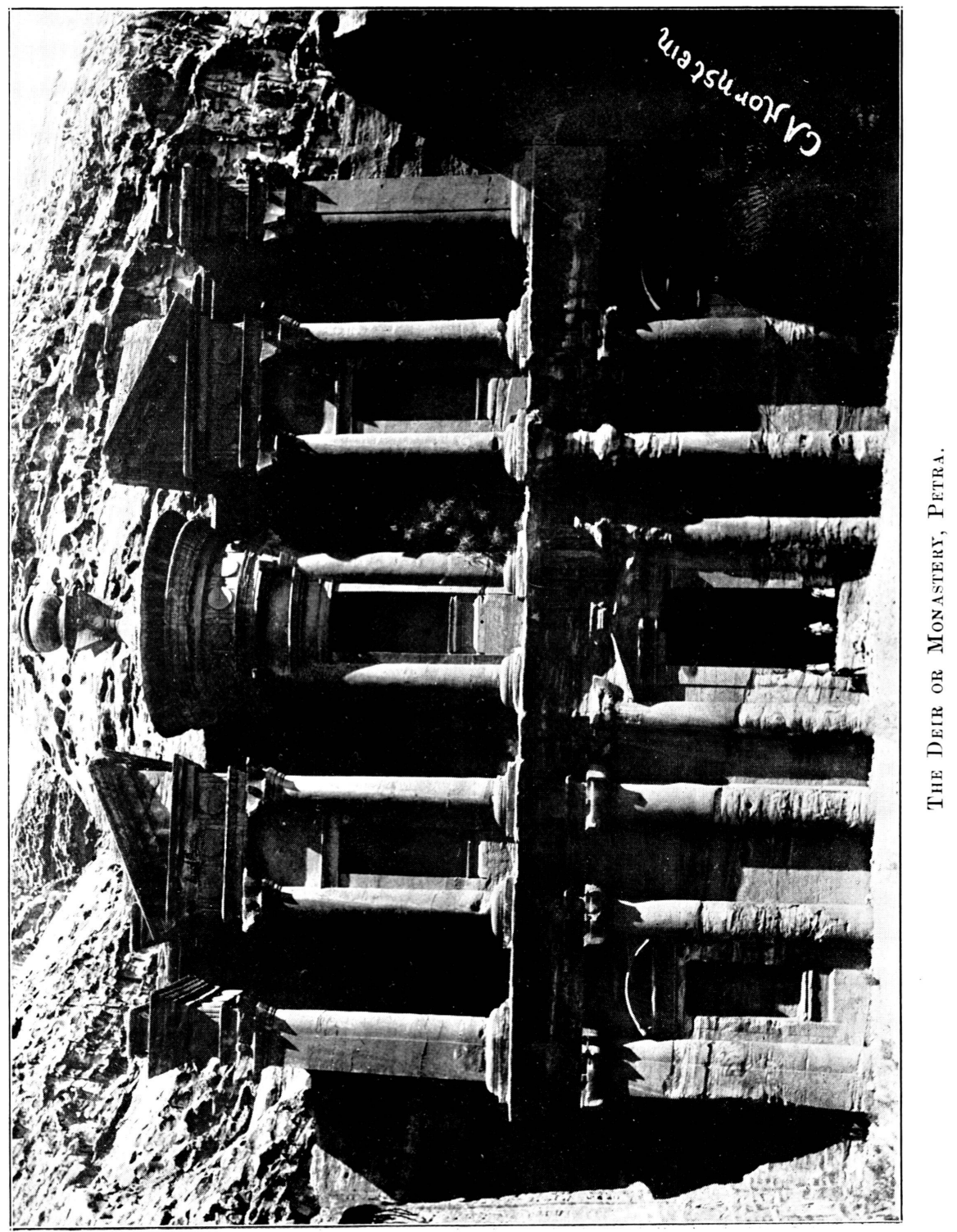


is a large building which the Bedouin cell Kasr Phar'aun (Pharaoh's Palace). The walls on three sides are nearly entire. Near this again are the remains of a church and the ruins of a castle. Leaving our horses with the soldiers and sheikhs, and taking the two villagers, who accompanied us, to carry the camera, we ascended a ravine to the northwest. The rocks here are of variegated colours; purple, black, red, shading off into each other. At several places we came to steps cut in the rock. After half an hour's climbing and scrambling we reached the top; here we found a large open space or platform, surrounded by high rocks. Facing the south-west and cut out of the solid white limestone rock is a large temple, called the Deir or monastery. It is much larger than any of the other temples, though not nearly so magnificent as the Khasneh with regard to colouring and design. It is 151 feet long by 142 feet high. The façade is ornamented with columns and niches, but no figures whatever. There may at one time have been images or statues in the niches, but these have entirely disappeared. On the top of the dome over the middle niche is an urn like the one surmounting the Khasneh. The interior consists of one large room, 36 feet 9 inches by 39 feet 8 inches. At the north end is a recess for an altar, with two steps, on either side, leading up to it; it is 14 feet wide by 8 feet deep, and raised 4 feet above the level of the floor. We noticed two holes on each side of the recess in the angles of the walls, above the steps, such as are made to tie animals to. It is possible that these were used to secure the animals brought for sacrifice. The doorway is 30 feet high and 17 feet wide.

Opposite the Deir, at the south-west end of the platform, is a rock with a level top, from which we got a magnificent view of Mount Hor in the distance.

Retracing our steps to the Kasr, which we reached about midday, we found that the two sheikhs had gone on to some Bedouin, called the Bedoul, who were living in the caves to the south of the ruins, to prepare some dinner for us. We followed them, and soon reached the dwelling (?) of a miserable-looking family, with hardly any clothing on. They had already killed a kid, and were boiling it. After dinner we rested a while, and then told the sheikhs that we would like to go to Jebel Haroon, Mount Hor. They refused to listen to such a thing, for they said if they took us up some evil would assuredly befall them before the year was out. We laughed at this and told them we would go by ourselves. Seeing we were determined, they tried to dissuade us by saying it was too late, and we should not get back till late at night. However, we told them we would try, so, starting up a very rough and rocky path, we reached the top of the wady. From here we had a magnificent view of the mountain, which still seemed a long way off. The Arabs had said the truth when they told us we should not get back till night. The sun was already near the horizon, and would have set by the time we reached the top, so that it would have been impossible to take any photos, as I had hoped to. 
Knowing that our time was linited, and that we could not return the next day to ascend the mountain, we decided that the only thing to be done was to get as near as possible and take a photo. Crossing the plain, we rode to the top of a little hill, from which we got a very good view.

Mount Hor is composed of sandstone of different shades. It has two peaks. On the north-east peak is situated the tomb of Aaron. We could see the white dome and little square building enclosing the tomb. It was a great disappointment not to be able to ascend. Retracing our steps we passed the Kasr, the Khasneh, and through the Sik. It was quite dark by the time we reached Elji. The next morning we rode down to the Sik, to take a view I had not been able to get the day before.

We returned to the village and lunched, then rode up to 'Ain Mâsa.

- It is a stream flowing out between two rocks, which latter have been ornamented with bits of rag and sticks by the pilgrims who come to visit this sacred place.

Leaving 'Ain Mâsa, we took the road north-east to Shobek (see map), which we reached at sunset. The next day brought us to Tafileh. Leaving here soon after midnight we got to Wad el Ahsa about 8 o'clock. Here we rested at the waterside and had some breakfast, then crossing the valley a little higher up than on the former occasion, we came to a watermill. A rough path led us to the plain above. Turning to the north-west we reached the ruins of Datras. The first ruin is that of a small temple facing the south. On each side of the door is a niche: The stones are large and well dressed. The Arabs call this Kasr el Bint, the Palace of the Girl. It is said that the daughter of a sheikh who lived here had such wonderful eyesight that she saw the enemy coming when they were still two days journey off. A little to the north-west of this Kasr are the ruins of the city of Datras. The gate, which is triple, like those at Lejune, and part of the city wall, are still standing. On the lintels are some carvings. Passing through the gateway, we came to a mass of ruins with columns lying about. We had not much time left to examine these ruins thoroughly, as it was getting late, and we wished to reach Kerak that evening. We noticed a great many rock-cut cisterns around the city. Leaving Datras we rode across the plain to Ja'far. The tomb is an ordinary Weli. The Mutassarif had specially asked me to take a photo of the dome. It has withstood the ravages of time, although it was apparently built without mortar, the stones having been so shaped as to form a dome.

From here we rode through the village of Moteh, and reached Kerak soon after sunset. We called on the Mutassarif, and gave him a brief account of our trip, which we had enjoyed so much.

Taking leave of the kind Kerak friends, I returned to Jerusalem by the usual route across the Mojeb, or Arnon, to Madeba and Jericho. I should like to mention two things:-The first is about Lejune. On the Palestine Exploration Fund map it is marked as being at least 30 miles from Kerak, but it is not more than 12 miles. The second is Datras. There are two places marked on the map-one Datras, 


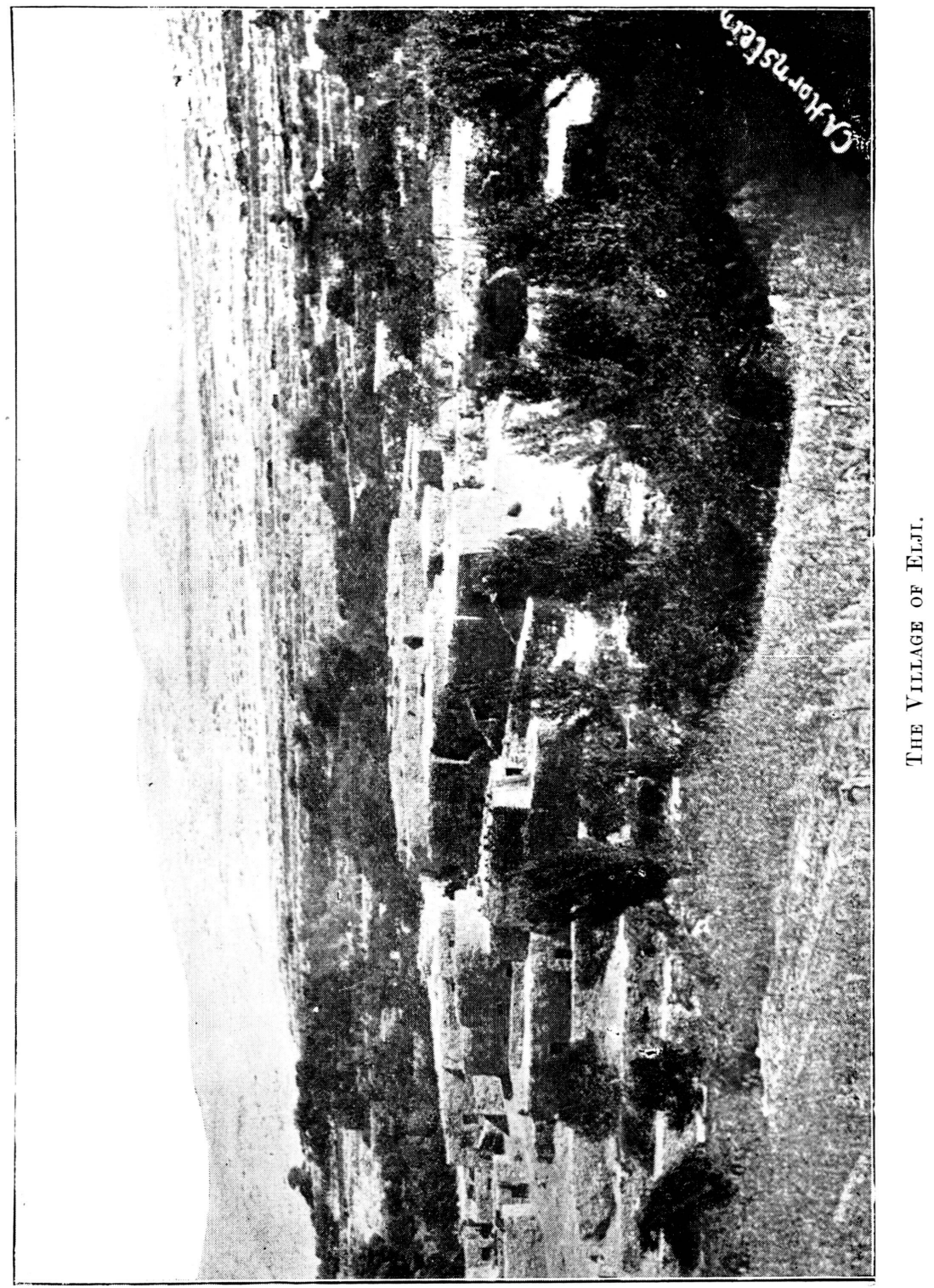


a little over three miles; and the other Zatras, about 15 miles to the south-east of Kerak. The latter, Zatras, corresponds to the one we visited. The soldiers and Bedouin who were with us called it Datras. About the former I could get no information ; it appears to be unknown.

\title{
JEWISH MEASURES OF CAPACITY.
}

\author{
By Colonel C. M. WAtson, C.M.G., R.E.
}

IN a paper which 'as published in the Quarterly Statement for July, 1897, on the proballe "Length of the Jewish Cubit," I gave some reasons for concluding that it was approximately $17 \cdot 7$ inches, subject to a slight correction on either side of this figure.

I did not, however, allude to the connection between the length of the cubit and the contents of the Jewish measures, and as this is a question of cousiderable interest I now propose to make some remarks with regard to it.

The Jews had two scales of measures of capacity : one for things dry, such as grain, \&c., and one for things liquid.

The various measures on the two scales are usually given as follows, and there seems no reason to doubt the correctness of the proportions:-

Dry Measure.

\section{Homer.}

Epha $=\frac{1}{10}$ homer.

Seah $=\frac{1}{3}$ epha.

Omer $=\frac{1}{30}$ epha.

$\mathrm{Cab}=\frac{1}{6}$ seah.
Liquid Measure.

Kor.

Bath $=\frac{r}{10}$ kor.

Seah $=\frac{1}{3}$ bath.

Hin $=\frac{1}{2}$ seah.

$\log =\frac{1}{12}$ hin.

Of these measures, the homer was equal in capacity to the kor, and the epha to the bath, while the seah was common to both scales. If, therefore, the bath or the seah was known there would be no difficulty in fixing the capacity of the other measures. But, unfortunately, there is considerable difference of opinion as to the capacity of the bath, and as a natural result the contents of all the measures vary, as given by different writers on the subject.

Neither in the Bible nor in the works of Josephus is there any accurate information, probably because both Josephus and the writers of the Sacred Books were well acquainted with the measures and did not realise the tromble that they would cause students many centuries later. Josephus, for example, states that a hin was equal to two Athenian choas, but this was probably only approximate, and as the Athenian choa is not very accurately known, it is not mush help. What is required is an expression of the cubic content of a measure in terms of 